\title{
LEADERSHIP STYLE OF NGO'S CONTRIBUTION TO GENDER AND SUSTAINABLE ENVIRONMENT DEVELOPMENT IN YOGYAKARTA PROVINCE OF INDONESIA
}

\author{
Shanta Sheema Akhter \\ Dhaka University, Bangladesh \\ E-mail: sheemashanta@yahoo.com
}

\begin{abstract}
Leadership Style of NGO's Contribution to Gender and Sustainable Environment Development in Yogyakarta Province of Indonesia. The main purpose of this study was to determine kind of leadership style used in the selected NGOs in Yogyakarta province in Indonesia and to analyze the optimal contributions of gender and sustainable environment development of their NGOs of Yogyakarta province in Indonesia. Qualitative research case study method was used to analyze this study. Data was collected by documentation, direct observations and interview. Sample was selected from two NGOs purposively: WALHI Yogyakarta and Mitra Pranata. The subjects of this study were the leaders, staffs and members of Mitra pranata and WALHI Yogyakarta NGO in Yogyakarta in Indonesia. Data was collected from two NGO leaders, from all staffs and selected members. The results showed that these NGO's leader used Transformational leadership style. WALHI Yogyakarta NGO has good achievements for Yogyakarta environment including- forest, spring, mine and others because they work about three aspects -policy research, campaign and organizing community. Mitra Pranata NGO also has good achievements. They work in small areas in Lendah village, Kulon Progo.
\end{abstract}

Keywords: achievement of gender and sustainable environment development, leadership style, NGO contribution

\begin{abstract}
Abstrak: Kontribusi Gaya Kepemimpinan LSM pada Gender dan Pembangunan Lingkungan Berkelanjutan di Provinsi Yogyakarta, Indonesia. Tujuan utama dari penelitian ini adalah untuk memahami bagaimana gaya kepemimpinan LSM tersebut dan menganalisis apa kontribusi LSM pada bidang gender dan pembangunan lingkungan yang berkelanjutan di Yogyakarta, Indonesia. Metode studi kasus kualitatif digunakan untuk menganalisis penelitian ini. Pengumpulan data dilakukan dengan dokumentasi, observasi langsung dan wawancara. Sampel dipilih dari dua LSM purposif: WALHI Yogyakarta dan Mitra Pranata. Subyek penelitian ini adalah para pemimpin, staf dan anggota Mitra pranata dan WALHI Yogyakarta. Data dikumpulkan dari dua pemimpin LSM, semua staf dan anggota yang dipilih. Hasil penelitian menunjukkan bahwa pemimpin LSM ini menggunakan gaya kepemimpinan transformasional. LSM WALHI Yogyakarta berkontribusi dalam bidang lingkungan di Yogyakarta termasuk-hutan, sumber mata air, tambang dan lain-lain karena bidang LSM tersebut meliputi tiga aspek penelitian yakni kebijakan, kampanye dan pengorganisasian masyarakat. Mitra Pranata LSM juga memiliki prestasi yang baik. Mereka bekerja di daerah terpencil di Desa Lendah, Kulon Progo.
\end{abstract}

Kata kunci: gaya kepemimpinan, kontribusi LSM, pencapaian gender dan pembangunan lingkungan yang berkelanjutan 


\section{INTRODUCTION}

An organization has vital roles for social development. Leader is the important factor in an organization and leadership style is the most important function of leaders. However NGO is such an organization which has an important role for social development. Mpabanga and Lekorwe (2007: 3) defined, "these are organizations which pursue activities to relieve the suffering, promote interests of the poor, protect the environment, provide basic social services, and undertake community development".

Nowadays gender and sustainable development are the conventional issues in the world. As a developing country, gender and environment are also vital issues in Indonesia. Fatimah (2010: 9) stated that "... this country is located at one of the most active disaster hot spots in the planet. Indonesia also faces various kinds of disaster like earthquake, tsunami, volcano eruption, flooding, landslide, draught and forst fires ". Arif, et al. (2010: $10)$ said, " by considering differences in the labour participation rate between men and women, the proportion of the female working poor is higher. There are 216 male working poor (21.6\%) for every 1000 male worker but 238 female working poor (23.8\%) for every 1000 female workers ".

Mitra pranata and WALHI Yogyakarta are such NGOs, which work for gender and environement in Yogyakarta province in Indonesia. The goal of Mitra Pranata are creating gender equality in all fields, empowering children-daughters, empowering of women and empowering of vulnerable communities. WALHI Yogyakarta works for environmental advocacy, organizing community and campaign.
Many Indonesian NGOs have been involved in development activities since the colonial period. NGOs significantly grew in Indonesia from 1970s. Most NGOs were established for an alternative development of the government development model. Most of the Indonesian NGOs are working for poverty reductions, woman empowerment and environments.

NGOs has a great contributions to gender and sustainable environment developmental expenditures in Indonesia. Therefore, the leaders of such NGOs also has great contributions for development. As NGOs activities are very emergent for development, this is very important to have knowledge the leadership style of the NGOs. So, this study is to recount and analysis the leadership style of NGO's contribution to gender and sustainable environment development in the WALHI Yogyakarta and Mitra Pranata of Yogyakarta province of Indonesia.

There are six research problem statements, namely: 1) What is the leadership style of these two leaders ? 2) What is the staff's role to achieve the organizational successes? 3) What is the achievement for gender and sustainable environment from these NGOs? 4) Why do they use this style in their NGOs? 5) How is the relationship of these style and their achievements? And 6) What is the benefit of this leadership style?

There are some studies supporting this present study : the first is a study by Arora (2012: 172) about NGO leadership style. This study was discussed about requirements of NGO leaders. Moreover this study also says, communication skill and managing performance are the requirements of best NGO leaders. 
The second is a study by Awan, Qureshi, \& Arif (2012: 52). This study try to examine the relationships among servant leaders, employees motivation and employees' work performance. That results shows the positive and significance relationships between servant leaders and employees' motivation and ultimately employees' work performance ".

The third study has been conducted by Sheehan (1993: 1). According to Sheehan, it is argued that such a view provides real choices and opportunities for NGOs to improve their effectiveness. So that study was discussed about effectiveness of participatory management in NGO sectors.

For the fourth study, Khankhoje \& Kumar (2004: 18) mentioned in their research "advances in women leadership styles: implications on subordinates competencies in an NGO- an empirical investigation" that the promotion of transformational type of leadership in the NGO sector, particularly in the developing nations, could be considered as a highly desirable pre-requisite and hence should warrant specific attention. Actually, that study was emphasized on transformational leadership style for NGO sectors. So it can be concluded that, above research studies discussed about NGO leaders requirements, the effective leadership style in NGO's, participatory management styles in NGO and advances of women leadership style. However all studies are related with NGO leadership. But present study have identified the leadership style of NGOs contribution to gender and sustainable environment development in Yogyakarta province of Indonesia.

\section{METHOD}

This study was conducted by qualitative method with a case study approach. This study focused on the leadership style and the contribution of gender economic and water spring manage-ment activities of these two NGO- WALHI Yogyakarta and Mitra Pranata. A case study approach used to understand and analyze of these two NGO leadership style and their contribution for gender economic and water spring management.

This research was conducted in two NGOs, Mitra pranata and WALHI Yogyakarta. The location of Mitra Pranata office is Jalan sukun no-124c Mancasan LOR, Condongcatur Depok Sleman, Yogyakarta, Indonesia. This NGO was selected for gender economic development. WALHI Yogyakarta was selected for environment. The location of this NGO is Jl. Nyi Pembayun 14 A Karangsamalo, Kota Gede, Yogyakarta 55172. This NGO was selected for sustainable environment development.

The primary observation time was January to March 2013 to identify the research problems. In this time, data was taken from these two NGOs by questionnair and interview. Interview data was taken by oral and writing from these two NGOs leaders. However, the second observation time was held from December 2013 to February 2014. It was taken by direct observation, interview and content analysis. The subjects of this study was chosen the leaders, staffs and members of Mitra pranata and WALHI Yogyakarta NGO in Yogyakarta province in Indonesia.

Data was collected from two NGO leaders, from all staffs and selected members to understand the leadership 
style through interview. The researcher was selected the leadership style to understand the contribution of gender and sustainable environment development through NGOs. Data collection techniques that were used in this research were direct observations, interviews, documents and vedio recordings. Data validity was measured by Yin (2009: 114) three principles : 1) Principle 1 : Multiple source of evidence 2) Principle 2: Create a case study database 3) Principle 3: Maintain a chain of evidence. Data was analyzed according to Miles and Huberman (1984 : 23) four steps : Data collection, Data display, Data reduction and Data conclusion.

\section{FINDINGS AND DISCUSSION WALHI Yogyakarta NGO}

The interviews were done with all key persons of WALHI Yogyakarta NGO. Key persons are (He), (Su), (Mu), (Ha), (Ri) and (Si). According to six research questions, the findings from WALHI Yogyakarta interviews and observations are given below.

According to number first research question, WALHI Yogyakarta leader uses participative approach to complete his missions. His positive sides - he is a good monitor, use advocacy style and discussions, directly work with community and negative side- sometime he can not implement his plan. He helps by providing evaluations, directions and giudience to staff. He does not give any reward to his staff. But, he gave some trainings for professional improvements instead of rewards. If any staff fails their work, then he tries to re-evaluate his or her work and sometimes he gives the responsibility to other and he accomplish the WALHI Yogyakarta missions by volunteers. Some interview data are given here:
Pemimpin WALHI Yogyakarta, gaya kepemimpinannya bagus yaitu low profile atau merakyat. Dalam menyelesaikan masalh NGO, sangat partisipatif. Menyelesaikan misi dengan NGO juga bagus, bagaimana ia bermitra dengan jaringan diskusi-diskusi untuk membahas masalahmasalah yang ada di NGO dan di WALHI Yogyakarta itu sendiri. (He/27/12/13).

Kelebihan-Low profil memberikan kontribusi mudah melakukan komunikasi dengan masyarakat karena setalah berbabur dari masyarakat, seolah olah dia adalah bagian dari masyarakat. Kekurangan- Pemimpin baru sehingga perlu pengalaman yang cukup untuk berbaur dan bisa menyelesaikan visi dan misi organisasi perlu banyak waktu dan program untuk bisa menyelesaikan visi dan misi (Su/13/1/2014).

...Seorang pemimpin terus memberikan kontribusi, advice dan peluang untuk mengkuti pelatihan-pelatihan yang berhubungan dengan isu tertentu, pelatihan pemetaan, pelatihan tentang digitasi, dsb. Dia selalu memberikan peluang untuk belajar bersama. Itu digunakan supaya bisa membantu dalam menyelesaikan visi dan misi NGO (Su/13/1/14).

Kalau ada kegagalan, itu adalah kegagalan bersama. Otomatis dilihat dari misalnya itu tidak tercapai, itu akan dievaluasi ulang, di mana letak kegagalannya itu dan akan diperbaiki. Tidak ada beban bahwa ini adalah kesalahan staf atau koordinator. Ini menjadi substansi kesalahan dibuat dengan sehingga atau PJ itu membuat 
kesalahan dengan sengaja akan dikeluarkan (He/27/12/13).

According to number second research question, WALHI Yogyakarta staff conduct some researches and the positive side of his staff are conscious for communication and negative side of his staff are still lacking in capacity building. Some interview data are given here -

...staff sesuai dengan mekanisme kerja organisasi dan rencana kerja tahunan (REKAT),staff divisi advokasi Kelebihan: Dia punya komitmen untuk bekerja dalam tim. Karena sudah kenal satu sama lain, komunikasi bisa berjalan bisa didiskusikan apa masalahnya. Komunikasi dua arah. Kekurangan: Secara kaderisasi masih kurang setingga ada beberapa staf yang membutuhkan penguatan kapasitas. Jadi secara prinsip dasar, mereka bisa melaksanakan tanggung jawab mereka artinya mereka bisa melaksanakan visi misi organisasi (Ha/22/12/13).

kawasan yang secara langsung berinteraksi dengan masyarakat melakukan pendampingan dan pengorganisasian masyarakat staff penguatan kelembagaan melakukan kajian dan riset dalam mendukung kerja-kerja advokasi yang dilakukan oleh divisi advokasi kawasan staff kesekretariatan melakukan pengelolaan keuangan dan administrasi sehingga divisi advokasi kawasan dan penguatan kelembagaan terbantukan dalam keuangan untuk operasional dan urusan administrasi (Ha/22/12/13).

According to number third research question, community gets indirectly help from WALHI Yogyakarta by KOMBI and FORSIDAS organization. Some relevant data are given below -

Keuntungan itu harapannya dimiliki masyarakat sehingga harapannya bagaimana sumber daya air itu dikelola deh masyarakat di sekitarnya sehingga manfaat bisa digunakan manfaat bisa digunakan secara maksimal oleh masyarakat sekitar. Dalam menggunakan/ memenafaatkan sumber daya air itu, kalau bisa dibentuk lebih baik sehingga perlu dibentuk kelompok pengguna sumber daya air. Sehingga yang pertama bagaimana membentuk kelompok yang bisa mengelola atau memanajeman pemanfaatan sumber daya air tadi (Ha/22/12/13).

We have close relation with WALHI Yogyakarta. If we got some problems, then always consults with WALHI Yogyakarta, specially for advocation. Actually Forsidas has collaboration with WALHI Yogyakarta, and this is one of the result. Before it was personal collaboration, then Pak Superlan (Director of WALHI Yogyakarta) said me to make an organization and then we make this (Ag/1/2/14).

Untuk teman teman WALHI Yogyakarta memberikan pemahaman, pengertian baik teman teman KOMBI maupun ke masyarakat. Supaya menjaga lingkungan di situ. Supaya menanam, tananam tananam keras. Sekarang sampai yang di situ di tebang, ga menanam lagi. Kalau bisa kita tanami lebih banyak lagi, beir identitas mata airnya. Kalau bisa ya, yang meningkat, kalau belum bisa yang penting stabil untuk pengartiyan 
dalam bantuan berwujud barang,itu belum, tapi lebih ke motivasi pemberi semangat ( $\mathrm{Pr} / 8 / 2 / 14)$.

According to number four research question, WALHI Yogyakarta leader is flexible but good achievement.

Lebih banyak bertindak daripada berbicara dan komunikasi lebih banyak dilakukan melalui tulisan, minim komunikasi verbal". Memberikan tugas yang dapat meningkatkan kemamampuan dan kapasitas, fleksibilitas dengan tetap mempertahankan nilai-nilai dasar organisasi, apa yang boleh dan apa yang tidak boleh dan melakukan evaluasi bersama (Ri/9/12/13).

According to number five research question, WALHI Yogyakarta leader has done many evaluations and plan, therefore they can help to community. Relevant data are given below -

Evaluasi bulanan mengevaluasi program, Rapat bulanan rencana program, Pertemuan anggota lembaga WALHI Yogyakarta per satu tahun mengevalusai program kerja setahun dan Pertemuan tahunan anggota WALHI Yogyakarta membahas program setahun kedepan (Si/9/12/13).

According to number six research question, the benefit of WALHI Yogyakarta leadership style is good, therefore community people are concern to use their water spring.

"meningkatkan kapasitas dan pengetahuan advokasi lingkungan melalui pelatihan baik yang diselenggarakan oleh internal maupun lembaga mitra dan jaringan WALHI Yogyakarta" (Ha/21/12/13).

Moreover, Kerja-kerja advokasi harus sesuai dengan nilai-nilai dan STATUTA WALHI adanya mekanisme organisasi yang mengatur hak dan kewajiban se-tiap staff WALHI Yogyakarta. Setiap staff membuat jurnal harian, laporan per-jalanan kegiatan dan laporan narasi kegiatan/program (Ha/22/12/13).

\section{Mitra Pranata NGO}

The interviewes done with all key person of Mitra Pranata NGO. However, the key persons are Mitra Pranata staff (Ut) and Mitra Pranata leader ( $\mathrm{Na}$ ). According to six research questions, the findings from Mitra Pranata leader and staff interviews and observations are the following:

According to number first research question, Mitra Pranata leader motivates community women. She has enough potential to develop the rural women. She helps her staff by consultation. She appriates her staff instead of direct reward. Her style is to motivate the community women. If her staff fails to conduct any work, she evaluates her work and gives solution. she does not have any strict rules for staff. Some relevant data are given below -

Dalam membantu masyarakat pemimpin saja selalu memberi gagasan atau ide yang bagus, yang baik, yang cemerlang untuk membantu masyarakat. Pemimpin saya juga selalu memberikan motivasi dan dorongan untuk masayarakat agar mereka mau maju dan berkembang dan itu juga menurut saya sangat menepung aspirasi dari masyarakat, permasalahan apa yang ada dalam masyarakat, kemudian nantinya 
sama-sama dicari pemecahan masalahnya atau solusinya. Kalau untuk menyelesaikan misi NGO, ingin mengembangkan masyarakat yang memiliki potensi agar mau mengangkat potensinya terutama masyarakat di pedesaan. Dalam menyelesaikan misi ini, otomatis selalau membuat langkah-langkah dan strategi yang cemerlang untuk kemajuan masyarakat karena memang untuk masyarakat (Ut) 24/12/13).

According to number second research question, Mitra Pranata staff give technical and operational supports. The positive side of Mitra Pranata staff is active, complete her work on time and the negative side of her satff is part time worker and so time shortage problem.

Staff bekerja sesuai dengan instruksi pekerjaan, selalau memberikan solusi atas persoalan atau permasalahan, yakni membantu memecahkan masalah, sekaligus memberikan masukan untuk hal-hal bersifat teknis opera-sional dalam menyelesaikan masalah NGO (Na/24/12/13).

Sangat displin dalam melaksanakan pekerjaan. Hal ini yang sangat menonjol. Keterbatasan: Part time sehingga tidak selalu bisa bertemu. Keterbatasan waktu tidak ada masalah dengan staff ( $\mathrm{Na} / 24 / 12 / 13)$.

According to number third research question, community get directly help from Mitra Pranata leader. Relevant data is given below -

From the previous documents analysis, the contribution of Mitra Pranata for gender development within 2004 to 2008 was very good. According to this document, Mitra Pranata works in four areas: training, research, empowerment of poor women, scientific activities with partners organizations. According this document, Mitra Pranata worked for "Education and training program" for women for batik marketing management in Mendiro, Gulurejo, Lendah, Kulonprogo, Yogyakarta special region, 19-21 Decem-ber, 2013. Mitra Pranata also trained for "Entrepreneurship and Business Management training" for the women at the Women's Empowerment Program in Jakarta in 2008, UNILEVER cooperation with UNESCO. Moreover, this orgization conducted "Training Development Instructional Materials Gender perspective Cooperation" with the Plan Indonesia inYogyakarta which was held on 1-3 February 2008.

According to number four research question, Mitra Pranata leader has significant achievements by her problem solving leadership style. Relevant data is given below-

Cukup signifikan, kami lokasi melihat perkembangannya income meningkat, kami sudah membangun komitmen di lapangan dengan pengrajin batik ini di Kulon Progo, kita akan menguatkan menjadi sentral batik dan nanti akan ditandai dengan patung ibu yang sedang membatik. Itu jangka menengah. Jangka pendek: Yang sudah ada, penguatan kelembangaan dengan membentuk koperasi yang berbadan hukum dan kami akan menjadi mediator mereka untuk mencarikan pinjaman modal yang sangat berpihak pada rakyat kecil maksimal bunga $1 / 2 \%$ per bulan. Yaitu embrio koperasi dan jangka menengah kami akan menguatkan mereka menjadi sentra batik. Jangka panjang, mungkin daerah wisata, 
yakin untuk diintegrasikan dengan budaya setempat, makanan, minuman khas disusun (Na/24/12/13).

According to number five research questions, Mitra Pranata leader build consciousness for gender economic development of community poor women by batik crafts. Relevant data are given below -

Kami selalu berusaha menyeleksi resume itu, pertama sesuai dengan potensinya. Jadi kami, komunitas batik di dusun itu ada sekitar 129 orang pengrajin batik, kami seleksi menjadi 85 orang. Saya anggap inilah yang potensial.Sedangkan kalau NGO yang sesuai kebutuhan dan yang potensial. Misalnya ini lebih kepada pemasaran (Na/24/12/13).

Kami selalu bersaha untuk mengoptimalkan kinerja mereka. Misalnya: Sudah buat sendiri, sudah punya modal, sudah punya buruh. Yah, jadi majikan, dia harus tetap melakukan kontrol terhadap buruhburuhnya/pembatiknya, misalnya hasil desainnya apakah waktu dia membatik banyak tetesan-tetesan dari itu kan merusak, itu kurang bagus. Dia harus melakukan kontrol itu. Agar optimal. Kami lihat hasil produk, pewarnaannya (Na/24/12/13).

According to number six research question, Mitra Pranata leader has successful outcomes for gender economic development. Relevant data are given below -

Baik ke masyarakat dan ke NGO, kami membangun langkah-langkah yang harus dikerjakan (itu strateginya) dan menyelesaikan setiap tahap berdasarkan skala prioritas.Jadi langkah-langkah apa saja untuk kemajuan masyarakat dan NGO, kami meletakkan. Skala prioritas misalnya: Pengrajin batik, dia sudah dapat bantuan kerja sama dari AUSAID itu ada obat batik pewarna tempat produksi. Lalu problemnya dalam pemasaran. Kami bantu secara material dengan AUSAID lalu kami lebih kepada pemasarannya untuk memperbaiki desain produk sampai produksi melalaui pameran/exhibition (Na/24/12/13).

Beerel (2010: 68) said, "Transformational leaders as those who inspire others to achieve extraordinary outcomes and in the process develop their own leadership capacity". Transformational leaders align the genuine needs of followers with the objectives and goals of the leader, the group and the larger organization. Transformational leaders are also credited with seeking to satisfy the higher needs to followers. They attempt to engage the full person; to develop a relationship of mutual stimulation and, as a result, take both parties (followers and leaders) to higher moral ground.

Beerel (2010: 68) said four critical components of Transformational leadership that they considered in their research time as follows: (a) Idealized Influence. Transformational leaders serve as role model for followers. They are admired, respected, trusted and followers want to emulate them. (b) Inspiration and Motivation. Transformational leaders motivate and inspire those around them by providing meaning and challenge to their followers work. (c) Intellectual Stimulation. Transformational leaders stimulate their followers effort to be innovative and creative by questioning assumptions, reframing problems and 
finding new approaches to solving old problems. (d) Individualized Consideration. Transformational leaders are especially attentive to each followers needs for achievement and growth. Followers fell personally cared for and are seen and treated as more than just employees. Transformational leaders act as coaches and mentors.

According to above four components, it can be concluded that WALHI Yogyakarta leaders leadership style is Transformational leadership. Because, it was identified that WALHI Yogya-karta leader is very helpful for his staff, because he gives evaluation and guidan-ce which is cover idealized influence components. WALHI Yogyakarta leader provides an opportunity to learn together which is cover inspiration and motivation.

WALHI Yogyakarta leader is flexible, teach his staff to become volunteer and give some internal training insted of direct reward which cover to individualized consideration, the achievement of WALHI Yogyakarta leader for water spring management activity is good and now community can use maximum water spring, which is cover Intellectual simulation component.

In addition, Mitra Pranata leaders leadership style is Transformational leadership. Because, it was identified, that Mitra Pranata leader always gives motivation and encourage to community, that makes her staff to be more concerned about social problem which is cover also Idealized influence components.

Mitra Pranata leader always gives motivation or encouragement the staff to create ideas and opinions for community issues which is cover Insperation and motivation components. However, Mitra Pranata leaders achievement are good because those women are powerful their families which is cover Intellectual stimulation components. Finally, Mitra Pranata leader never gives any reward to her staff, but she always appriates for her good achievement. Sometimes she gives big responsibility instead of reward which is cover Individualized consideration component.

\section{CONCLUSION}

Based on the research findings and discussions, WALHI Yogyakarta and Mitra Pranata leaders have good contributions for gender economic and water springs for environment development. Therefore, the conclusion of the leadership style of NGO contribution to gender and sustainable environment development in Lendah village for 85 women, Gambiran community for Tirto Wening Spring and Jepitu village for Puring Spring in Yogyakarta province of Indonesia can be drawn as follows. First, According to the discussion, they use transformational leadership style because they are good mentors and evaluators, influencers to their staffs, intellectuals means their significant achievements and motivators instead of giving rewards according to their NGO missions. Second, according to the discussions, both leader's leadership style and achievements have good relationship. Therefore, they use transformational leadership style and get good benefits from this style for their organizations. Third, both leader use transformational leadership style. Moreover, WALHI Yogyakarta leader has contributed to sustainable environment development by water spring management activities by FORSIDAS and KOMBI organization for Gambiran community and Jepitu village people in Kotagede and Gunung Kidul. However, Mitra Pranata leader has contributed to gender economic 
development in Lendah village on 85 batik maker women by her organization.

\section{REFERENCES}

Arif, S., Syukri, M., Holmes, R., \& Febriany, V. 2010. Gendered Risks, Poverty, and Vulnerability: Case Study of the Raskin Food Subsidy Programme in Indonesia. London: ODI.

Arora. N. 2012. "An Exclusive Study Of Ngo's Leaders Working Style". International Journal of Management \& Information Technology, 1(3), from cirworld.com. Retrived on July 2 , 2013.

Awan, K.Z., Qureshi, I.E.W., \& Arif, S. 2012. "The Efffective Leadership Style in NGO's: Impact of Servant Leadership Style on Employees' Work Performance And Mediation Effect of Work Motivation". International Journal of Economics and Management Sciences, 1(11), 43-56, from www. managementjournals.org. Retrived on September 18, 2013.

Beerel, A. 2009. Leadership and Change Management. ( $1^{\text {st }}$ ed.). London: Sage Publication.
Fatimah, D. 2012. Refused to Surrender: Gender and Agency in Disaster Risk Reduction. (English Version). Yogyakarta: Aksara.

Khankhoje, Kb., \& Kumar. 2004. "Advances in Womens Leadership Styles: Implications of Subordinates Competencies in an NGO-An Empirical Investigation", from www.c.ymcdn. com. Retrived on January 5, 2014.

Lekorwe, M., \& Mpabanga, D. 2007. "Managing Nongovernmental Organizations in Botswana". The Innovation Journal: The Public Sector Innovation Journal, 12(3), from http://www. innovation.cc/scholarly-style/. Retrived on September 10, 2013.

Miles, M., \& Huberman, A. 1994. Qualitative Data Analysis: An Expanded Source Book. ( $2^{\text {nd }}$ ed.). Thousand Oakes: Sage.

Sheehan. 1998. "NGOs andparticipatory management styles: a case study of CONCERN Worldwide, Mozambique", from www.eprints.lse.ac.uk. Retrived on January 5, 2014.

Yin, R.K. 2009. Case Study Research Design and Methods. ( $4^{\text {th }}$ ed.). California: Sage Publication. 